\title{
David Oliver: Choosing to be honest about patient choice
}

\section{David Oliver consultant in geriatrics and acute general medicine}

Berkshire

Henry Ford said in 1909 about his Model T car, "You can have any colour you like, so long as it's black." He wanted the first mass produced, no frills car to be affordable to ordinary families. They lapped it up: sales grew exponentially for 20 years. ${ }^{1}$

The NHS was founded with similar spirit and results. A basic, universal offer minus deluxe customised features, it was a godsend to many previously unable to afford care and was taken up enthusiastically. ${ }^{2}$ Seventy years on, it still sits high in international rankings for equity, universality, and cost. ${ }^{3}$ It's the institution most valued in opinion polls. ${ }^{4}$

It does worse on the trade-off indices of consumerism and choice. ${ }^{5}$ Modern citizens are used to wide choice, information, and digital access in retail, leisure, and communications. Policy makers wonder whether a less paternalistic, monolithic offer is now expected in healthcare. The excellent NHS Choices website is full of information and advice. ${ }^{6}$

But we need some realism about choice and personalisation in the current NHS funding model. Firstly, I'm not convinced that these are many patients' biggest priorities. When surveyed, people most value proximity, access, and ease of transport to local GPs and acute hospitals (especially in crisis), ${ }^{78}$ and familiarity, trust, and continuity in practitioners. ${ }^{9}$

The NHS Choose and Book service had fairly low uptake and confused many people. ${ }^{10}$ Many would rather doctors use their local knowledge to refer: how often do doctors consult league tables when seeking specialist care, even for their own or a relative's treatment?

Secondly, I perceive an increasingly orthodox groupthink. It assumes that we all (should) want to live healthy lifestyles and remain well, to become "activated" patients taking more responsibility for our conditions, to control our health records or personal health budgets, and to "self manage" problems in equal partnership with trained clinicians.

But not everyone does want this. And others are, for various reasons, unable to take this on.
I perceive an increasingly orthodox groupthink. It assumes that we all want to become "activated" patients taking responsibility for our conditions

Our template of what we think patients should want often seems to be based on system pressures. That is: to keep away from emergency departments at all costs, perhaps seeing a pharmacist instead; or to choose telephone GP consultation over face to face-never to want a few more days in hospital before leaving or to choose a care home instead of staying at home. If patients do want that, are we saying it's a product of false consciousness and not true patient choice? That they just don't know what's available or what's good for them?

Patients can have any choice they want, so long as it's the cheaper, more convenient one we'd prefer them to make. Let's stop pretending otherwise.

Competing interests: See www.bmj.com/about-bmj/freelancecontributors/david-oliver.

Provenance and peer review: Commissioned; not externally peer reviewed.

1 Hart M. Why did Henry Ford say "A customer can have a car painted any color he wants as long as it's black"? Quora 11 May 2015. https://www.quora.com/Why-did-Henry-Fordsay-\%E2\%80\%9CA-customer-can-have-a-car-painted-any-color-he-wants-as-long-asit $\%$ E2\% $80 \% 99$ s-black\%E2\%80\%9D.

2 Campbell D. Nye Bevan's dream: a history of the NHS. Guardian 18 Jan 2016. https:// www.theguardian.com/society/2016/jan/18/nye-bevan-history-of-nhs-national-healthservice.

3 Oliver D. David Oliver: The best health system. BMJ 2016;357:11848. doi:10.1136/bmj. i1848 pmid:27044632.

4 Gershlick B, Charlesworth A, Taylor E. Health Foundation. Public attitudes to the NHS: an analysis of responses to questions in the British Social Attitudes Survey. Feb 2015. www.health.org.uk/publication/public-attitudes-nhs.

5 Health Consumer Powerhouse. Euro health consumer index 2016. 30 Jan 2017. www. healthpowerhouse.com/files/EHCI 2016/EHCI 2016 report.pdf.

healthpowerhouse.com/files/EHCl_2016/EHCl_

$\begin{array}{ll}6 & \text { NHS Choices. www.nhs.uk/pages/home.aspx. } \\ 7 & \text { Knox A. Nuffield Trust. Public perspectives on the NHS. } 2 \text { Mar 2017. https://www. }\end{array}$ nuffieldtrust.org.uk/news-item/public-perspectives-on-the-nhs\#public-concern-about-thenhs-is-growing.

8 King's Fund. Patient choice: how patients choose and how providers respond. Jun 2010. https://www.kingsfund.org.uk/projects/patient-choice-how-patients-choose-and-howproviders-respond.

9 National Voices. A narrative for person-centred coordinated care. May 2013. www. nationalvoices. org.uk/publications/our-publications/narrative-person-centred-coordinatedcare. 
10 Swinglehurst D, Greenhalgh T, Stones R. What went wrong in the demise of Choose and Book?[article]. Health Serv J2014;357. https://www.hsj.co.uk/comment/what-went-wrongin-the-demise-of-choose-and-book/5072570.
Published by the BMJ Publishing Group Limited. For permission to use (where not already granted under a licence) please go to http://group.bmj.com/group/rights-licensing/ permissions 